\title{
A Tentative study of Learning Styles and Vocabulary Learning Strategies of Non-English Majors in Minority Academy
}

\author{
HE Wei \\ School of Foreign Languages, \\ Wuhan Textile University \\ Wuhan, China \\ lexicraze@wtu.edu.cn
}

\begin{abstract}
This dissertation focuses on investigating in Chinese cultural contexts the relationship between learning styles and vocabulary learning strategies on non-English majors in minority academy. The study applies Quantitative method, questionnaire and vocabulary knowledge test to investigate and analyze learners' uses of vocabulary learning strategies and how the two independent factors influence the English achievement among those non-English majors in minority academy. At the same time, the paper points out the differences of learning strategies used by the high and the low proficiency students. The major findings can be stated as follows: (1) Chinese EFL learners used a variety of strategies in vocabulary learning; (2) the high proficiency students (HPS) did better in the employment of indirect strategies and used most of the direct strategies, except keyword and translation, more frequently than the low proficiency students (LPS); Finally, it puts forward some limitations of present study and suggestions for future work in this field.
\end{abstract}

Keywords-learning style, vocabulary learning strategy, non-English majors in minority academy

\section{INTRODUCTION}

At present, increasing numbers of people in the world noticed the importance of acquiring learning skills. Now the definition of illiterate refers to people who don't know how to learn. Nowadays the education department has called for quality-oriented education, which means to focus on teaching how to learn to improve learners' learning ability. With the rapid change of the society, it is of significant importance to assist learners in acquiring basic skills. In 1970s, some researchers put forwards that second-language acquisition and second-language learning has been likely to change from teachers' teaching to students' learning and more and more studies have been done from students-oriented points (Chamot, 1987). A lot of studies point out that language is a skill that can be acquired only through the efforts made by the learner himself. So, Linguists and researchers has changed their study from the learning product to the learning process. What' more, increasing numbers of researchers has analyzed the relations among learning styles, learning strategies and the process of learning, and how these factors promote autonomous learning.

\section{RESEARCH PURPOSE}

The former studies have showed that the most successful learners are those who use learning strategies effectively and proved that acquiring learning strategies is the best approach for second language acquisition. However, Oxford (1990) points out "not only the language learning process itself but also the input into this process should be considered" (pp. 15). "Input" here refers to "different students' and teachers' characteristics, such as sex, intelligence, personality, previous experience, teaching styles, general learning, attitudes, motivation and so on". It is presumed that a lot of factors has influence on successful language learning besides effective learning strategies. Aiming at helping learners to get better understanding of second language learning processes and strategies, Stern (1983) calls for further research "at different ages and maturity levels, and at different levels of proficiency, in different social contexts, under different language learning conditions"(pp. 412). So, learners should be trained to exert one's advantages and make up for one's disadvantages according to one's different characterizes.

This dissertation attempts to investigate the relationship between learning styles and vocabulary learning strategies, and analyze these two factors' influence on English achievement tests.

\section{DESIGN AND IMPLEMENTATION}

\section{A. Subjects}

In May 2014, 54 sophomores in 2 classes in Non-English Majors in South-Central University for Nationalities responded to the Vocabulary Learning Strategies Questionnaire and English Vocabulary Test. Among the 54 subjects, there were 37 females and 17 males. The age group ranges from 19 to 21 with an average of 20 .

\section{B. Instruments}

\section{Questionnaire}

In this study, the researcher adopts The Vocabulary Learning strategy Questionnaire, which consists of two parts and is written in English. The first part is about the information of personal profiles. The second part is 37 statements concerning vocabulary learning behaviors, 
which examines the frequency with which learners use strategies in their vocabulary learning. And this paper adopts a five-point scale according to Oxford's classification of learning strategies. So the learners who got higher marks are those who use the strategy more frequently. This design is based on the paper" Self-testing on other factors affecting one's learning strategies" written by Professor Wen Qiufang's.

- Vocabulary knowledge test

60 vocabulary questions at the level of CET4 (College English Test) were chose from model tests for English majors and the test was given half a month before the national TEM.

Data collection and analysis

All the questionnaires were collected within the set time. The vocabulary proficiency test was carried out instantly after the questionnaire was filled. The researchers adopted SPSS (Statistical Program for Social Sciences) to assist in analyzing the date. At first, descriptive statistics are employed to observe the overall patterns of vocabulary learning strategies used by the leatrners, and then T-tests were adopted to make a comparison between the strategies used by the high-proficiency and low-proficiency students.

\section{RESULTS AND DISCUSSION}

A. Vocabulary learning strategies used by the students

\begin{tabular}{|l|l|l|l|}
\hline \multicolumn{4}{|c}{ TABLE 1 } \\
\hline Strategies & Classification & Mean & Std.Deviation \\
\hline $\begin{array}{l}\text { Metacognitive } \\
\text { Strategies }\end{array}$ & Selective attention & 3.3815 & 1.0400 \\
\cline { 2 - 4 } & Self-initiation & 3.8852 & 0.9869 \\
\hline Social Strategies & & 2.6667 & 1.0640 \\
\hline Affective Strategies & 3.8519 & 0.8655 \\
\hline \multirow{2}{*}{$\begin{array}{l}\text { Compensation } \\
\text { Strategies }\end{array}$} & Contextual guessing & 3.7185 & 0.8896 \\
\cline { 2 - 4 } & Immediate context & 3.5408 & 0.9294 \\
\hline \multirow{4}{*}{$\begin{array}{l}\text { Strategies } \\
\end{array}$} & Grouping & 3.1222 & 0.9772 \\
\cline { 2 - 4 } & Repetition & 3.7037 & 1.0925 \\
\cline { 2 - 4 } & Keyword & 2.1481 & 1.2650 \\
\cline { 2 - 4 } & Translation & 2.8333 & 1.0047 \\
\hline \multirow{3}{*}{$\begin{array}{l}\text { Strategies } \\
\end{array}$} & Analyzing & 3.5741 & 0.9437 \\
\cline { 2 - 4 } & Association & 3.3148 & 0.9679 \\
\cline { 2 - 4 } & Practicing & 3.2963 & 0.9737 \\
\cline { 2 - 4 } & Summarizing & 3.6111 & 0.9400 \\
\hline
\end{tabular}

From table 1, the result of this investigation showed that: (1) Metacognitive strategies (self-initiation and selective attention) were more frequently used by the learners (the mean score is from 3.3815 to 3.8852 ). That means the students could regulate their own learning consciously. (2) Affective strategies were in the same situation as metacognitive strategies. That means the students could control their own emotions and feelings properly while learning. (3)Unexpectedly, the frequency of social strategies was much lower than the former two. That means the students were lacking in communication and consultation with others while facing learning obstacles. (4) All the cognitive strategies and compensation strategies were frequently adopted by the learners. The order of the mean scores was arranged from high to low: contextual guessing, summarizing, analyzing, immediate context, practicing and association. That means compensation strategies are comparatively more popular than most of the cognitive strategies. (5)The uses of memory strategies were interiorly different. It could be classified into two groups. One was grouping and repetition with the mean scores 3.1222 and 3.7037 while the other one was keyword and translation with the mean scores 2.1481 and 2.8333 .

B. Vocabulary learning strategies adopted by low-proficiency students and high-proficiency students

The major criterion for identifying high-proficiency students (HPS) and low-proficiency students (LPS) was the total score the learners got on the vocabulary knowledge test. It is found that 15 subjects with the highest total scores, out of the 54 subjects, were chosen for high-proficiency students and 15 with the lowest total scores for low-proficiency students. T-tests were adopted to compare the differences between vocabulary-learning strategies used by LPS and the ones used by HPS. From Table 2, we find that the differences of strategies in vocabulary learning between HPS and LPS.

\begin{tabular}{|c|c|c|c|c|c|c|c|}
\hline \multirow[b]{2}{*}{ Strategies } & \multirow[b]{2}{*}{$\begin{array}{l}\text { Classificati } \\
\text { on }\end{array}$} & \multicolumn{2}{|l|}{ HPS } & \multicolumn{2}{|l|}{ LPS } & \multirow[b]{2}{*}{$\mathrm{df}$} & \multirow[b]{2}{*}{$\begin{array}{l}\text { T-Val } \\
\text { ue }\end{array}$} \\
\hline & & Mean & SD & Mean & SD & & \\
\hline \multirow{2}{*}{$\begin{array}{l}\text { Metacog } \\
\text {-nitive } \\
\text { Strategies }\end{array}$} & $\begin{array}{l}\text { Selective } \\
\text { attention }\end{array}$ & 3.49 & 1.11 & 3.16 & 1.20 & 28 & 4.385 \\
\hline & $\begin{array}{l}\text { Self-initiati } \\
\text { on }\end{array}$ & 3.98 & 0.81 & 3.77 & 1.10 & 28 & 3.527 \\
\hline \multicolumn{2}{|c|}{ Social Strategies } & 2.59 & 1.12 & 2.53 & 0.83 & 28 & 2.833 \\
\hline \multicolumn{2}{|c|}{ Affective Strategies } & 3.95 & 0.88 & 3.73 & 0.93 & 28 & 3.581 \\
\hline \multirow{2}{*}{$\begin{array}{l}\text { Compens } \\
\text { ation } \\
\text { Strategies }\end{array}$} & $\begin{array}{l}\text { Contextual } \\
\text { guessing }\end{array}$ & 3.89 & 0.88 & 3.58 & 0.92 & 28 & 3.243 \\
\hline & $\begin{array}{l}\text { Immediate } \\
\text { context }\end{array}$ & 3.58 & 0.80 & 3.47 & 1.05 & 28 & 1.538 \\
\hline \multirow{4}{*}{$\begin{array}{l}\text { Memory } \\
\text { Strategies }\end{array}$} & Grouping & 3.13 & 0.86 & 2.88 & 1.08 & 28 & 2.006 \\
\hline & Repetition & 3.53 & 0.94 & 3.73 & 1.28 & 28 & $\begin{array}{l}-2.23 \\
2\end{array}$ \\
\hline & Keyword & 2.06 & 1.14 & 2.27 & 1.39 & 28 & 2.027 \\
\hline & Translation & 2.55 & 0.88 & 2.93 & 1.25 & 28 & 3.623 \\
\hline \multirow{4}{*}{$\begin{array}{l}\text { Cognitive } \\
\text { Strategies }\end{array}$} & Analyzing & 3.60 & 0.87 & 3.40 & 1.18 & 28 & 2.854 \\
\hline & Association & 3.38 & 1.07 & 3.20 & 1.08 & 28 & 3.017 \\
\hline & Practicing & 3.40 & 0.94 & 3.20 & 1.00 & 28 & 5.136 \\
\hline & $\begin{array}{l}\text { Summarizi } \\
\text { ng }\end{array}$ & 3.82 & 0.73 & 3.27 & 1.00 & 28 & 2.741 \\
\hline
\end{tabular}

The result shows that the mean scores of $78 \%$ strategies used by HPS were higher than the ones used by LPS in vocabulary learning. HPS did better in metacognitive strategies, while the frequency of both selective attention $(\mathrm{M}=3.49, \mathrm{SD}=1.11)$ and self-initiation $(\mathrm{M}=3.98, \mathrm{SD}=0.81)$ were higher than LPS'. Thus HPS were able to adapt themselves to different situations for the purpose of learning. In terms of social strategies and affective strategies, the situation was quite similar. That's why HPS could always keep their head and communicate with teachers and other students well. Among 
compensation strategies, HPS used contextual guessing $(\mathrm{M}=3.89, \mathrm{SD}=0.88)$ and immediate context $(\mathrm{M}=3.58$, $\mathrm{SD}=0.80$ ) more frequently than LPS. That means HPS used the context more often to help them understand the word even when they never met them before. In addition, HPS used cognitive strategies more widely. They followed a relatively more flexible set of procedures for analyzing. For example, they use dictionaries to find the various meanings of the word together with examples and the usage of the word. They are more inclined to associate the word with a similar one and memorize them together, and then practise and summarize them more frequently. The most obvious differences between the two groups are in the use of memory strategies. Among grouping, repetition, keyword and translation, the uses of the latter 3 by HPS are lower than that by LPS. HPS dexterously grouped the words in accordance with hyponymy, derivation, syntactic function etc. LPS used repetition $(\mathrm{M}=3.73, \mathrm{SD}=1.28)$, keyword $(\mathrm{M}=2.27, \mathrm{SD}=1.39)$ and translation $(\mathrm{M}=2.93, \mathrm{SD}=1.25)$ more widely.

\section{SUGGESTIONS AND IMPLICATIONS}

\section{A. Suggestions}

The findings in the present study that English learning strategies and learning styles to some extent account for the effects on English achievement and that the HPS used English learning strategies much more often than the LPS, provide teachers with pedagogical insights and imply the significance of monitoring students' learning styles and learning strategy use. By understanding students' cognitive processing, teachers can diagnose and adjust teaching activities subjective to individual differences. For example, insisting that differences in learning styles may mean that some strategies are more useful for one learner than another, teachers should take this into consideration when designing teaching materials and organizing in-class activities.

\section{B. Limitations of this study}

The samples in the study are only sophomores of Non-English Majors in South-Central University for Nationalities, which limits the practical value of the present study.

The study only concentrated on the vocabulary learning strategies, so most of the results can only be applied to vocabulary learning process but not others.

- The present research just merely adopted questionnaires as the only Data collection techniques. The potential problem is that those responses normally couldn't really reflect the real situation and status of students' learning processing.

\section{REFERENCE}

[1] Chamot, A.U. (1987). The language strategies of ESL students. In A.L. Wenden \& J.Rubin (eds.), Learner strategies in language learning (pp. 89-91). London: Prentice-Hall International Ltd.
[2] Ellis, R. (1985). Understanding second language acquisition. New York: Oxford University Press.

[3] Nunan, D. (1995). Language teaching methodology: A textbook for teachers. Prentice Hall International

[4] Oxford, R.L. (1990). Language learning strategies. In: What every teacher should know (pp. 1-47). New York: Harper \& Row.

[5]Stern, H.H. (1983). Fundamental concepts of language teaching. New York: Oxford University Press 